\title{
PENGARUH CORPORATE GOVERNANCE DAN VARIABEL KEUANGAN TERHADAP NILAI PERUSAHAAN
}

\author{
DEWI AGUSTINA
}

\author{
STIE Trisakti Jakarta \\ dewiagustina2780@yahoo.com
}

\begin{abstract}
The purpose of this study is to determine and examine corporate governance (board of commissioner, independent commissioner, institutional ownership, managerial ownership and audit committee) and financial variabel measured by financial ratio such as leverage, activity, profitabilityand liquidity in affecting firm value in non financial companies listed in Indonesia Stock Exchange. This research used 91 listed non financial companies in Indonesia Stock Exchange, selected using purposive sampling method in period 2013 to 2015. The analysis was performed using multiple linear regressions analysis method to determine the model of research. The research results show that the board of commissioner, managerial ownership, leverage and profitability had influence towards firm value whereas, the independent commissioner institutional ownership, audit committee, activity and liquidity had no influence towards firm value.
\end{abstract}

Keywords: Firm Value, Corporate Governance, Leverage, Activity, Profitability, Liquidity

\begin{abstract}
Abstrak: Tujuan penelitian adalah untuk mengetahui dan menguji apakah corporate governance (dewan komisaris, dewan komisaris independen, kepemilikan institusional, kepemilikan manajerial, dan komite audit) dan variabel keuangan yang diukur dengan rasio keuangan seperti leverage, aktivitas, profitabilitas dan likuiditas memiliki pengaruh terhadap nilai perusahaan di perusahaan non keuangan yang terdaftar di Bursa Efek Indonesia. Penelitian ini menggunakan 91 perusahaan non keuangan yang terdaftar di Bursa Efek Indonesia yang dipilih menggunakan metode purposive sampling dalam periode 2013 sampai 2015. Data penelitian ini dianalisis menggunakan metode analisis regresi linear berganda dalam model penelitian.Hasil dari penelitian ini menunjukkan bahwa ukuran dewan komisaris, kepemilikan manajerial, leverage, dan profitabilitas berpengaruh terhadap nilai perusahaan. Sedangkan komisaris independen, kepemilikan institusional, komite audit, aktivitas dan likuiditas tidak memiliki pengaruh terhadap nilai perusahaan.
\end{abstract}

Kata Kunci: Nilai Perusahaan, Corporate Governance, Leverage, Profitabilitas, Aktivitas, Likuiditas 


\section{PENDAHULUAN}

Setiap perusahaan didirikan dengan suatu tujuan, baik tujuan jangka pendek maupun tujuan jangka panjang. Tujuan jangka pendek yang ingin dicapai perusahaan yaitu memaksimumkan laba. Sedangkan tujuan jangka panjangnya adalah mencapai nilai perusahaan secara maksimal (Suroto 2015). Menurut Ridwan dan Gunardi (2013), nilai perusahaan pada dasarnya dapat diukur melalui beberapa aspek, salah satunya adalah dengan harga pasar saham perusahaan, karena harga pasar saham perusahaan mencerminkan penilaian investor secara keseluruhan atas setiap ekuitas yang dimiliki.

Pengukuran variabel keuangan dapat dilakukan dengan menghitung rasio keuangan yang tercantum dalam laporan keuangan yang telah diterbitkan dan dipublikasikan (Putra dan Wirawati 2013). Dalam penelitian ini, variabel keuangan dapat digambarkan dengan leverage ratio, rasio aktivitas, rasio likuiditas dan rasio profitabilitas. Rasio tersebut berperan dalam menciptakan kinerja keuangan yang efektif yang juga berdampak pada penciptaan nilai perusahaan.

Menurut Mukthtaruddin et al. (2014), perusahaan yang mempunyai corporate governance yang baik akan meningkatkan nilai perusahaan. Dengan adanya mekanisme GCG ini diharapkan monitoring terhadap manajer perusahaan dapat lebih efektif sehingga dapat meningkatkan kinerja perusahaan dan nilai perusahaan (Wardoyo dan Veronica 2013).

Penelitian ini merupakan pengembangan dari penelitian sebelumnya yang dilakukan oleh Mukthtaruddin et al. (2014). Dalam penelitian sebelumnya menggunakan variabel corporate governance yang terdiri dari jumlah dewan komisaris, dewan komisaris independen, kepemilikan institusional, kepemilikan manajerial, dan keberadaan komite audit, variabel CSR Disclosure, serta variabel control yaitu tipe industri dan profitabilitas yang berpengaruh terhadap nilai perusahaan.
Sedangkan perbedaan penelitian ini dengan penelitian sebelumnya yaitu dengan adanya penambahan variabel independen lainnya yang digunakan dalam menentukan faktor-faktor yang dapat memengaruhi nilai perusahaan. Adapun variabel independen lain yang digunakan dalam penelitian ini adalah kinerja perusahaan yaitu leverage dan aktivitas (Sianturi 2015) dan likuiditas Timbuleng et al. (2015).

Masalah penelitian yang dapat diuraikan adalah apakah terdapat pengaruh ukuran dewan komisaris, dewan komisaris independen, kepemilikan institusional, kepemilikan manajerial, komite audit, profitabilitas, leverage, aktivitas, likuiditas terhadap nilai perusahaan.

Motivasi dari penelitian ini adalah untuk mendapatkan bukti empiris sejauh mana terdapat pengaruh ukuran dewan komisaris dewan komisaris independen, kepemilikan institusional, kepemilikan manajerial, komite audit, profitabilitas, leverage, aktivitas, likuiditas terhadap nilai perusahaan.

Penelitian ini diharapkan dapat membantu investor mengetahui memberikan informasi bagi investor dalam melakukan analisis terhadap perusahaan serta sebagai bahan pertimbangan dalam pengambilan keputusan investasi pada perusahaan di masa yang akan datang. Bagi Perusahaan, hasil penelitian ini diharapkan dapat membantu para penyelenggara perusahaan untuk mengevaluasi serta meningkatkan kinerja perusahaan dalam rangka mencapai tujuannya serta meningkatkan nilai perusahaan. Sedangkan bagi peneliti selanjutnya penelitian ini diharapkan dapat menjadi bahan referensi dan memberikan informasi-informasi yang berguna untuk penelitian selanjutnya yang terkait dengan nilai perusahaan serta dapat memberikan wawasan dan pengetahuan baru atau tambahan bagi peneliti selanjutnya. 


\section{Teori Keagenan}

Teori keagenan adalah teori yang menjelaskan hubungan antara principal dan agent. Menurut Jensen dan Meckling (1976), hubungan keagenan diartikan sebagai kontrak dimana satu orang atau lebih (prinsipal) mempekerjakan atau menggunakan jasa orang lain (agen) untuk melakukan beberapa tindakan tertentu demi kepentingan mereka (prinsipal), yaitu melalui pendelegasian sebagian wewenang kepada agen untuk melakukan pengambilan keputusan.

Dalam konsep theory of the firm Jensen dan Meckling (1976), adanya agency problem menghambat perusahaan untuk mencapai tujuannya yaitu nilai perusahaan. Perusahaan dapat meminimalisir hal tersebut dengan penerapan mekanisme Good Corporate Governance (GCG) yaitu tata kelola perusahaan yang dapat menjalankan fungsi pengendalian dalam perusahaan sehingga pemegang saham lebih mudah untuk mengawasi dana yang diinvestasikannya dan memastikan bahwa dana tersebut sudah dikelola dengan tepat. Dengan adanya GCG ini, pengawasan terhadap manajer perusahaan dapat lebih efektif sehingga dapat meningkatkan kinerja perusahaan dan nilai perusahaan (Wardoyo dan Veronica 2013).

\section{Teori Sinyal}

Dorongan perusahaan untuk mengungkapkan informasi kepada pihak eksternal karena adanya asimetri informasi yang terjadi antara manajemen dengan pihak eksternal merupakan latar belakang timbulnya teori sinyal (Rosiana et al. 2013). Pada teori sinyal, informasi penting untuk diberikan kepada pihak eksternal perusahaan untuk mengatasi asimetri informasi tersebut. Informasi yang disampaikan kepada pihak eksternal seperti untuk pemegang saham harus lengkap, relevan, akurat dan tepat waktu karena informasi tersebut dibutuhkan oleh para investor di pasar modal sebagai alat analisis untuk melakukan keputusan investasi (Moeljadi dan Supriyati 2014).

\section{Nilai Perusahaan}

Indikator yang digunakan sebagai parameter untuk mengukur nilai perusahaaan adalah Tobin's $Q$ yang merupakan salah satu rasio yang paling rasional dan rasio ini dinilai bisa memberikan informasi yang paling baik, karena rasio ini bisa menjelaskan berbagai fenomena dalam kegiatan perusahaan yang membandingkan nilai pasar saham suatu perusahaan yang terdaftar di pasar keuangan dengan nilai penggantian asset. Tobin's Q memasukkan semua unsur hutang dan modal saham perusahaan, tidak hanya ekuitas perusahaan yang dimasukkan namun seluruh aset perusahaan (Sianturi 2015).

\section{Corporate Governance}

Prinsip-prinsip corporate governance yang diterapkankan memberikan manfaat diantaranya yaitu: (1) meminimalkan agency costs dengan mengontrol konflik kepentingan yang mungkin terjadi antara prinsipal dengan agen; (2) meminimalkan cost of capital dengan menciptakan sinyal positif kepada para penyedia modal; (3) meningkatkan citra perusahaan; (4) meningkatkan nilai perusahaan yang dapat dilihat dari cost of capital yang rendah, dan (5) peningkatan kinerja keuangan dan persepsi stakeholder terhadap masa depan perusahaan yang lebih baik (Herawaty 2008)

\section{Ukuran Dewan Komisaris}

Dewan Komisaris dalam perusahaan merupakan salah satu peran yang penting dalam pelaksanaan GCG. Dewan komisaris merupakan pusat ketahanan dan kesuksesan perusahaan. Dewan komisaris bertanggungjawab untuk memastikan strategi perusahaan, membutuhkan akuntabilitas dan bertanggung jawab untuk mengawasi manajemen dalam meningkatkan efisiensi, daya saing dan nilai perusahaan.(Mukhtaruddin et al. 2014). 
Hasil penelitian yang dilakukan oleh Mukhtaruddin et al. (2014), membuktikan bahwa ukuran dewan komisaris memiliki pengaruh positif terhadap nilai perusahaan namun tidak signifikan. Hal ini diakibatkan oleh proses pemilihan yang bukan dari rapat pemegang saham melainkan dari pendapat mayoritas perusahaan.

Berbeda dengan penelitian oleh Wardoyo dan Veronica (2013) yang menyatakan bahwa ukuran dewan komisaris tidak memiliki pengaruh terhadap nilai perusahaan sehingga penelitian ini menyimpulkan bahwa Ukuran Dewan Komisaris berpengaruh terhadap nilai perusahaan.

H1 Ukuran Dewan Komisaris berpengaruh terhadap nilai perusahaan.

\section{Dewan Komisaris Independen}

Wardoyo dan Veronica (2013) menyatakan bahwa komisaris independen yang memiliki minimal 30\% dari jumlah seluruh anggota komisaris, berarti telah memenuhi pedoman GCG guna menjaga independensi, pengambilan keputusan yang efektif, tepat, dan cepat. Diharapkan dengan adanya pengawasan langsung serta pengambilan keputusan yang lebih cepat, keberadaan dewan komisaris independen dapat meningkatkan nilai perusahaan.Berbeda dengan hasil penelitian dari Rupilu (2011) bahwa dewan komisaris independen tidak memiliki pengaruh terhadap nilai perusahaan.Pernyataan tersebut juga didukung oleh hasil penelitian dari Prastuti dan Budiasih (2015) serta Wardoyo dan Veronica (2013).Sedangkan penelitian yang dilakukan oleh Raro dan Mediatuty (2011) menyatakan terdapat pengaruh positif dewan komisaris independen terhadap nilai perusahaan.

H2 Dewan Komisaris Independen berpengaruh terhadap nilai perusahaan.

\section{Kepemilikan Institusional}

Borolla (2011) mengemukakan bahwa kepemilikan institusional merupakan saham perusahaan yang dimiliki oleh institusi atau lembaga dalam hal ini institusi pendiri perusahaan. Berbeda dengan hasil penelitian yang dilakukan oleh Borolla (2011), Herawaty (2008) serta Ridwan dan Gunardi (2013) yang menyatakan bahwa kepemilikan institusional berpengaruh positif namun signifikan terhadap nilai perusahaan. Sedangkan penelitian yang dilakukan oleh Prastuti dan Budiasih (2015) memiliki hasil berbeda yaitu terdapat pengaruh negatif kepemilikan institusional terhadap nilai perusahaan. Hasil berbeda dikemukakan oleh Purbopangestu dan Subowo (2014) yaitu kepemilikan institusional tidak berpengaruh terhadap nilai perusahaan.

H3 Kepemilikan Institusional berpengaruh terhadap nilai perusahaan.

\section{Kepemilikan Manajerial}

Menurut Mukhtaruddin et al. (2014), dengan adanya kepemilikan manajerial kepentingan manajemen atau pengelola perusahaan dan pemegang saham akan bersatu dan akan memberikan dampak positif untuk meningkatkan nilai pemegang saham. Nilai pemegang saham yang meningkat tentu akan meningkatkan harga saham yang dapat berdampak kepada nilai perusahaan. Hasil penelitian yang dilakukan oleh Mukhtaruddin (2014) menyatakan bahwa kepemilikan manajerial berpengaruh positif dan signifikan terhadap nilai perusahaan.Sejalan dengan hasil dari penelitian Ridwan (2013) dan Moeljadi dan Supriyati (2014) yang menyatakan adanya pengaruh positif signifikan kepemilikan manajerial terhadap nilai perusahaan.

Sedangkan hasil penelitian Herawaty (2008) menyatakan bahwa kepemilikan manajerial berpengaruh negatif terhadap nilai perusahaan. Hasil tersebut diperkuat oleh penelitian yang dilakukan oleh Rupilu (2011) dan Raro dan Mediatuty (2011). Prastuti dan Budiasih (2015), Borolla (2011) serta Pertiwi (2012) mengemukakan hasil yang berbeda yaitu dimana kepemilik- 
an manajerial tidak memiliki pengaruh terhadap nilai perusahaan.

H4 Kepemilikan Manajerial berpengaruh terhadap nilai perusahaan.

\section{Komite Audit}

Jika komite audit dapat melakukan tugasnya dengan baik, maka transparansi tanggung jawab manajemen perusahaan yang tertuang dalam laporan keuangan akan dapat percaya. Hal tersebut akan menarik perhatian pasar modal sehingga pada akhirnya akan meningkatkan nilai perusahaan (Mukhtaruddin et al. 2014). Hasil penelitian yang dilakukan oleh Mukhtaruddin (2014) menyatakan bahwa komite audit memiliki pengaruh positif namun tidak signifikan terhadap nilai perusahaan. Hasil penelitian tersebut konsisten dengan penelitian yang dilakukan oleh Ridwan (2013), Raro dan Mediatuty (2011) serta Rupilu (2011).

Berbeda dengan hasil penelitian dari Prastuti dan Budiasih (2015) yang menyatakan bahwa komite audit dalam perusahaan memiliki pengaruh yang positif terhadap nilai perubahan. Sedangkan menurut penelitian yang dilakukan oleh Purbopangestu dan Subowo (2014), komite audit tidak berpengaruh terhadap nilai perusahaan

\section{H5 Komite Audit berpengaruh terhadap nilai perusahaan.}

\section{Variabel Keuangan}

Variabel keuangan juga digunakan sebagai ukuran umum kondisi kesehatan perusahaan pada suatu periode, dan dapat digunakan sebagai perbandingan di antara perusahaan yang berada dalam jenis industri yang sama maupun industri yang berbeda (Gamayuni 2012). Variabel keuangan biasanya diproksikan dengan rasio keuangan. Rasio keuangan berkaitan dengan metode menghitung dan menafsirkan rasio keuangan untuk menganalisa dan memantau kinerja perusahaan (Gitman dan Zutter 2012).

\section{Profitabilitas}

Menurut Moeljadi dan Supriyati (2014), profitabilitas adalah kemampuan perusahaan untuk menghasilkan laba bersih dari aktivitas yang dilaksanakan di periode akuntansi.Hasil penelitian yang membuktikan hal tersebut adalah penelitian oleh Mukhtaruddin (2014), Dewi dan Wirajaya (2013), Kodir (2013), Pertiwi (2012). Profitabilitas memiliki pengaruh positif signifikan. Pernyataan tersebut diperkuat pula oleh penelitian yang dilakukan Putra (2013) serta Moeljadi dan Supriyati (2014).

H6 Profitabilitas berpengaruh terhadap nilai perusahaan.

\section{Leverage}

Leverage menurut Gitman dan Zutter (2012) adalah hasil penggunaan biaya tetap dari aset atau penggunaan pembiayaan untuk meningkatkan tingkat pengembalian bagi pemegang saham. Dalam penelitian yang dilakukan Sianturi (2015) terdapat hasil dimana leverage memiliki pengaruh negatif signifikan terhadap nilai perusahaan. Hasil penelitian ini konsisten dengan Kodir (2013).

Sedangkan menurut penelitian yang dilakukan oleh Rupilu (2011), leverage memiliki pengaruh yang positif terhadap nilai perusahaan. Terdapat pendapat yang berbeda bahwa tidak terdapat pengaruh leverage terhadap nilai perusahaan menurut penelitian yang dilakukan oleh Ogolmagai (2013) dan Timbuleng et al. (2015).
$\mathrm{H} 7$ Leverage berpengaruh terhadap nilai perusahaan.

\section{Aktivitas}

Rasio aktivitas (Activity ratio) menggambarkan hubungan antara tingkat operasi perusahaan dengan aset yang dibutuhkan untuk menunjang kegiatan operasi perusahaan tersebut (Gamayuni 2012). Pada penelitian sebelumnya, aktivitas tidak memiliki pengaruh yang signifikan seperti yang dinyatakan oleh Sianturi 
(2015) dengan indikasi bahwa investor kurang memperhatikan dan mempertimbangkan rasio aktivitas dalam berinvestasi pada perusahaan manufaktur karena pada umumnya rasio aktivitas perusahaan yang listing di Bursa Efek Indonesia sudah stabil.

Hasil ini diperkuat dengan hasil penelitian dari Ulupui I.G.K.A (2007) dan Saptono (2001) dalam Sianturi (2015) pada industri barang dan konsumsi kategori perusahaan makanan dan minuman di BEl yang menunjukkan bahwa secara parsial variabel aktivitas tidak berpengaruh terhadap nilai perusahaan.

H8 Aktivitas berpengaruh terhadap nilai perusahaan.

\section{Likuiditas}

Likuiditas merupakan kemampuan perusahaan untuk memenuhi kewajiban jangka pendeknya dengan menggunakan struktur modal mempunyai pengaruh terhadap jenis modal apa yang akan ditarik. Apabila jumlah modal yang dibutuhkan sangat besar, maka dirasa perlu bagi perusahaan tersebut mengeluarkan sekuritas secara bersama-sama begitu pula sebaliknya.Perusahaan yang memiliki likuiditas yang tinggi berarti perusahaan memiliki internal financing yang akan cukup digunakan untuk membayar kewajibanya sehingga struktur modal juga berkurang. liquidty akan mengurangi penggunaan debt Anjarwati,K.et al. (2016)

H9: Likuditas berpengaruh terhadap nilai perusahaan.

\section{METODE PENELITIAN}

Obyek penelitian yang digunakan sebagai populasi adalah perusahaan-perusahaan non keuangan yang terdaftar di Bursa Efek Indonesia. Pemilihan sampel dalam penelitian menggunakan pendekatan non probability random sampling dengan metode purposive sampling. Proses dalam menentukan sampel dalam penelitian ini ditunjukkan dalam tabel 1.
Dalam penelitian ini, variabel yang digunakan sebagai variabel dependen adalah nilai perusahaan diukur dengan skala rasio yaitu menggunakan Tobin's Q mengacu pada penelitian yang dilakukan oleh Mukhtaruddin et al. (2014) dengan rumus sebagai berikut:

$$
\mathrm{Q}=\frac{(\mathrm{EMV}+\mathrm{D})}{\mathrm{EBV}+\mathrm{D}}
$$

Keterangan:

$\mathrm{Q}=$ Nilai Perusahaan

EMV = Nilai Pasar Ekuitas (Equity Market Value) (Harga Penutupan Saham $\times$ Jumlah saham yang beredar yang dimiliki oleh perusahaan)

EBV = Nilai Buku Ekuitas (Equity Book Value)

$\mathrm{D}=$ Nilai Buku Hutang

Adapun variabel-variabel independen yang digunakan dalam penelitian ini adalah sebagai berikut Ukuran dewan komisaris diukur berdasarkan jumlah anggota dewan komisaris yang ada dalam perusahaan. Skala data adalah skala rasio. Rumus dalam pengukuran mengacu pada penelitian yang dilakukan oleh Mukhtaruddin et al. (2014):

\section{UDK $=\Sigma$ Anggota Dewan Komisaris}

Dewan komisaris independen diukur dengan rumus yang mengacu pada penelitian yang dilakukan oleh Mukhtaruddin et al. (2014) sebagai berikut: Skala data adalah skala rasio.

$$
\mathrm{DKI}=\frac{\sum \text { Komisaris Independen }}{\sum \text { Anggota Dewan Komisaris }}
$$

Kepemilikan institusional diukur dengan persentase kepemilikan saham institusional dalam perusahaan (Mukhtaruddin et al.2014). Skala data adalah skala rasio. Rumus yang digunakan dalam penelitian ini adalah sebagai berikut:

INST $=\frac{\text { Jumlah kepemilikan saham institusional }}{\text { Jumlah saham yang beredar yang dimiliki oleh perusahaan }}$ 
Kepemilikan manajerial diukur dengan persentase jumlah saham yang dimiliki oleh manajemen dalam perusahaan mengacu pada penelitian yang dilakukan oleh Mukhtaruddin et al.(2014). Skala data adalah skala rasio.

MNJRL $=\frac{\text { Jumlah kepemilikan saham manajerial }}{\text { Jumlah saham yang beredar yang dimiliki oleh perusahaan }}$

Seperti penelitian yang dilakukan oleh Mukhtaruddin et al. (2014), maka komite audit diukur dengan jumlah komite audit yang terdapat pada perusahaan.Skala data adalah skala ratio.

$\mathrm{KA}=\Sigma$ Anggota komite audit dalam perusahaan

Profitabilitas dalam penelitian ini diukur dengan skala rasio menggunakan Return on Equity (ROE). Rasio ini diukur yaitu dengan perbandingan laba bersih setelah pajak dengan total ekuitas mengacu pada penelitian yang dilakukan oleh Sianturi (2015).

$$
\text { ROE }=\frac{\text { EAIT }}{\text { Total Ekuitas }}
$$

\section{*EAIT = Earning After Income Taxes (pendapatan} bersih setelah pajak)

Leverage dalam penelitian ini diukur dengan skala rasio menggunakan Debt to Equity Ratio (DER) yaitu perbandingan total liabilitas dengan total ekuitas dengan rumus sebagai berikut (Sianturi 2015):

$$
\text { DER }=\frac{\text { Total Liabilitas }}{\text { Total Ekuitas }}
$$

Menurut Syahrial dan Purba (2011), rasio aktivitas menggambarkan kemampuan perusahaan memanfaatkan aktiva yang dimiliki dalam memperoleh penghasilan melalui penjualan. Dalam penelitian ini, rasio aktivitas diukur menggunakan perputaran total aktiva (Total asset tumover) sebagai berikut (Sianturi 2015):

$$
\text { TAT }=\frac{\text { Penjualan bersih }}{\text { Total aktiva }}
$$

Likuiditas adalah hasil perbandingan antara aktiva lancar dengan hutang lancar.Asset lancar adalah asset yang digunakan dalam waktu dekat Skala yang digunakan adalah skala rasio. Rumus menghitung likuiditas/ current ratio (Liq) adalah sebagai berikut Timbulenget al.(2015):

$$
\mathrm{CR}=\frac{\text { Aktiva Lancar }}{\text { Hutang Lancar }}
$$

\section{HASIL PENELITIAN}

Hasil data pengujian statistik ini mendeskripsikan tentang nilai terendah, nilai tertinggi, rata-rata hitung dan deviasi standar. Hasil statistik deskriptif dapat dilihat dari tabel 2. Hasil pengujian pada tabel 3 menunjukkan variabel Ukuran Dewan Komisaris (UDK) memiliki nilai signifikansi sebesar 0,000 , di mana nilai ini lebih kecil dari nilai alpha 0,05 , maka $\mathrm{H}_{\mathrm{a} 1}$ diterima. Hal ini mengartikan Ukuran Dewan Komisaris berpengaruh terhadap nilai perusahaan pada perusahaan non keuangan di Bursa Efek Indonesia. Hal ini menyimpulkan bahwa semakin banyaknya dewan komisaris maka pengawasan terhadap perusahaan akan lebih baik, nasihat dan masukan untuk manajemen pun akan lebih banyak. Maka dari itu, nilai perusahaan akan meningkat apabila jumlah dari dewan komisaris meningkat.

Variabel dewan komisaris independen (DKI) menunjukkan nilai sig. sebesar 0,073 lebih besar dari 0,05 sehingga dapat disimpulkan bahwa hipotesis alternatif kedua $\left(\mathrm{Ha}_{2}\right)$ tidak diterima. Hal ini menyimpulkan bahwa dewan 
komisaris independen tidak berpengaruh terhadap nilai perusahaan pada perusahaan non keuangan di Bursa Efek Indonesia.

Variabel kepemilikan institusional (INST) menunjukkan nilai sig. sebesar 0,817 lebih besar dari 0,05 sehingga dapat disimpulkan bahwa hipotesis alternatif ketiga $\left(\mathrm{Ha}_{3}\right)$ tidak diterima. Hal ini menunjukkan bahwa variabel kepemilikan institusional tidak berpengaruh terhadap nilai perusahaan pada perusahaan non keuangan di Bursa Efek Indonesia.

Variabel kepemilikan manajerial (MNJRL) menunjukkan nilai sig. sebesar 0,038 lebih kecil dari 0,05 sehingga dapat disimpulkan bahwa hipotesis alternatif keempat $\left(\mathrm{Ha}_{4}\right)$ diterima. Hal ini menunjukkan bahwa variabel kepemilikan manajerial berpengaruh terhadap nilai perusahaan pada perusahaan non keuangan di Bursa Efek Indonesia. Struktur kepemilikan yang terdiri dari kepemilikan manajerial dapat mempengaruhi jalannya suatu perusahaan, yang pada akhirnya akan mempengaruhi kinerja perusahaan dan juga maksimalisasi nilai perusahaan. Kepemilikan manajerial yang memiliki peran sebagai pengendali dalam pengambilan kebijakan perusahaan.

Variabel komite audit (KA) menunjukkan nilai sig. sebesar 0,270 lebih besar dari 0,05 sehingga dapat disimpulkan bahwa hipotesis alternatif kelima (Has) tidak diterima. Hal ini menunjukkan bahwa variabel komite audit tidak berpengaruh terhadap nilai perusahaan pada perusahaan non keuangan di Bursa Efek Indonesia.

Variabel profitabilitas (ROE) menunjukkan nilai sig. sebesar 0,000 lebih kecil dari 0,05 sehingga dapat disimpulkan bahwa hipotesis alternatif keenam $\left(\mathrm{Ha}_{6}\right)$. Hal ini menunjukkan bahwa variabel profitabilitas berpengaruh positif terhadap nilai perusahaan pada perusahaan non keuangan di Bursa Efek Indonesia. Hal ini menyimpulkan bahwa Return on Equity digunakan untuk mengukur kemampuan manajemen dalam mengelola modal yang tersedia dalam menghasilkan net income. Semakin baik kinerja manajemen perusahaan dalam menghasilkan pendapatan optimal dari modal yang ditanamkan maka semakin tinggi keuntungan yang dicapai yang berdampak pada semakin baiknya tingkat pengembalian yang akan diberikan pada pemegang saham. Hal tersebut dapat memberi sinyal positif kepada investor sehingga saham akan semakin diminati yang kemudian akan meningkatkan nilai perusahaan tersebut.

Variabel leverage (DER) menunjukkan nilai sig. sebesar 0,029 lebih kecil dari 0,05 sehingga dapat disimpulkan bahwa hipotesis alternatif ketujuh $\left(\mathrm{Ha}_{7}\right)$ diterima. Hal ini menunjukkan bahwa variabel leverage berpengaruh negatif terhadap nilai perusahaan pada perusahaan non keuangan di Bursa Efek Indonesia. $\mathrm{Hal}$ ini berarti Leverage berpengaruh negatif terhadap nilai perusahaan dikarenakan perusahaan yang memiliki tingkat utang yang tinggi akan menyebabkan beban bunga yang dibayarkan perusahaan juga tinggi. Hal tersebut akan mengurangi kemampuan perusahaan dalam menghasilkan laba dan hal ini mempengaruhi keputusan investor dalam menginvestasikan dananya atau membeli saham suatu perusahaan.

Variabel aktivitas (TAT) menunjukkan nilai sig. sebesar 0,460 lebih besar dari 0,05 sehingga dapat disimpulkan bahwa hipotesis alternatif kedelapan ( $\mathrm{Ha}_{8}$ ) tidak diterima.

Hal ini menunjukkan bahwa variabel aktivitas tidak berpengaruh terhadap nilai perusahaan pada perusahaan non keuangan di Bursa Efek Indonesia.

Variabel likuiditas (LIQ) menunjukkan nilai sig.sebesar 0,230 lebih besar dari 0,05 sehingga dapat disimpulkan bahwa hipotesis alternatif kedelapan (Has) tidak diterima. Hal ini menunjukkan bahwa variabel Likuiditas (LIQ) tidak berpengaruh terhadap nilai perusahaan pada perusahaan non keuangan di Bursa Efek Indonesia. 


\section{PENUTUP}

Berdasarkan pengujian regresi yang telah dilakukan hasilnya menunjukkan Ukuran Dewan Direksi, Kepemilikan Manajerial, Profitabilitas, Leverage berpengaruh terhadap nilai perusahaan pada perusahaan non keuangan di Bursa Efek Indonesia sedangkan Dewan Komisaris Independen, Kepemilikan Institusional ,Komite Audit, Aktivitas, dan Likuiditas tidak berpengaruh terhadap nilai perusahaan pada perusahaan non keuangan di Bursa Efek Indonesia dalam pengujian ini.

Adanya keterbatasan yang muncul dalam penelitian, seperti periode penelitian yang diambil oleh penulis hanya tiga tahun, yaitu dari tahun 2013 sampai 2015 dimana dapat dikatakan masih relatif pendek sehingga data dalam penelitian ini masih mengalami masalah uji asumsi klasik, yaitu heteroskedastisitas. Keterbatasan yang lain adalah terdapat variabel lain yang dapat memengaruhi nilai perusahaan yang tidak digunakan penulis di dalam penelitian ini sehingga variabel independen yang berpengaruh dalam model penelitian terbatas.

Penelitian selanjutnya diharapkan menambah periode penelitian menjadi lima tahun atau lebih sehingga penelitian selanjutnya terhindar dari masalah uji asumsi klasik. Penelitian lain diharapkan menambah variabel-variabel lainnya yang juga dapat memengaruhi nilai perusahaan yang ada seperti: Corporate Social Responsibility (CSR), kebijakan dividen, partumbuhan perusahaan, dan proksi lain dari kinerja keuangan maupun Corporate Governance.

\section{REFERENSI:}

Agustia, Dian. 2013. Pengaruh Faktor Good Corporate Governance, Free Cash Flow, dan Leverage terhadap Manajemen Laba, Vol. 15, No. 1: 27-42.

Anjarwati,K,Mochammad Chabachid,Irene R.D.P.2016.Pengaruh Profitabilitas,Size,dan Likuiditas terhadap Nilai Perusahaan Manufaktur di Indonesia dengan Struktur Modal sebagai Variabel Intervening.Studi Empiris Pada Perusahaan Manufaktur yang Terdaftar di Bursa Efek Indonesia Tahun 2012-2015. Program Magister Managemen Universitas Diponegoro

Borolla, J. D. 2011. Analisis Pengaruh Struktur Kepemilikan terhadap Nilai Perusahaan. Jurnal Prestasi, Vol. 7, No.1: 11-24.

Dewi, A. S. Mahatma,A. Wirajaya. 2013. Pengaruh Struktur Modal, Profitabilitas dan Ukuran Perusahaan pada Nilai Perusahaan. E-Jurnal Akuntansi Universitas Udayana 4.2, 358-372.

Eisenhardt, Kathleem. M. 1989. Agency Theory: An Assesment and Review. Academy of Management Review, Vol. 14, No. 1: 57-74.

F.Timbuleng., S.C. Nangoy.,I.S. Saerang.(2013).Pengaruh Faktor Likuiditas, Leverage, NPM dan ROI Terhadap NilaiPerusahaan (Studi pada Perusahaan Consumer Goods yang Terdaftar di Bursa Efek Indonesia Periode 2010-2013. Jurnal EMBA, Vol.1, No. 3:81-89. Universitas Sam Ratulangi Manado.

Forum for Corporate Governance in Indonesia (FCGI). 2011. What Is Corporate Governance.Diakses 27 Maret 2015 dari http://www.fcgi.or.id/corporate-governance/about-good-corporate-governance.html.

Gamayuni, Rindu Rika. 2012. Relevansi Kinerja Keuangan, Kualitas Laba, Intangible Asset, dengan Nilai Perusahaan.Jurnal Trikonomika. Vol. 11, No.2: 119-136.

Ghozali, Imam. 2013. Aplikasi Analisis Multivariate dengan Program IBM SPSS 21. Edisi Ketujuh. Semarang: Badan Penerbit Universitas Diponegoro.

Gitman, L., Zutter, C. 2012. Principles of Managerial Finance (13 th Edition). Boston: Pearson Education, Inc.

Godfrey, J., A. Hodgson, A. Tarca, J. H. Milton, S. Holmes. 2010. Accounting Theory 7thEdition. Australia: John Wiley \& Sons Australia. Ltd. 
Herawaty, V. 2008. Peran Praktek Corporate Governance sebagai Moderating Variable dari Pengaruh Earnings Management terhadap Nilai Perusahaan. Jurnal Akuntansi dan Keuangan, Vol. 10, No. 2. Universitas Trisakti Indonesia.

Irayanti, D., A. L. Tumbel. 2014. Analisis Kinerja Keuangan dan Pengaruhnya terhadap Nilai Perusahaan pada Industri Makanan dan Minuman di BEI. Jurnal EMBA 1473. Vol. 2, No. 3: 1473-1482.

Jensen, M.C.\& Meckling, W.H. 1999. Theory of The Firm: ManagerialBehavior,Agency Costs and Ownership Structure.Journal of Financial Economics, Oktober, Vol. 3, No. 4: 305-360.

Karuniasih, D. M. 2013. Pengaruh Good Corporate Governance terhadap Manajemen Laba pada Perusahaan Perbankan.Accounting Analysis Journal 2 (1).

Kodir, Muhammad. 2013. Pengaruh Faktor-Faktor Fundamental Perusahaan, Kurs dan Tingkat Bunga terhadap Nilai Perusahaan pada Perusahaan Manufaktur yang Terdaftar di Bursa Efek Indonesia. Jurnal Bisnis dan Manajemen (JBIMA), Vol. 1, No. 1: 56 - 65.

Komite Nasional Kebijakan Governance.2006. Pedoman Umum Good Corporate GovernanceIndonesia. Jakarta: Komite Nasional Kebijakan Governance.

Moeljadi, T. S. Supriyati. 2014. Factors Affecting Firm Value: Theoretical Study on Public Manufacturing Firms in Indonesia. South East Asia Journal of Contemporary Business, Economics and Law, Vol. 5, Issue 2: 6-15.

Mukhtaruddin, Relasari, M. Felmania. 2014. Good Corporate Governance Mechanism, Corporate Social Responsibility Disclosure on Firm Value: Empirical Study on Listed Company in Indonesia Stock Exchange.International Journal of Finance \& Accounting Studies, Vol. 2, No. 1.

Ogolmagai, Natalia. 2013. Leverage Pengaruhnya terhadap Nilai Perusahaan pada Industri Manufaktur yang Go Public di Indonesia. Jurnal EMBA, Vol.1, No. 3:81-89. Universitas Sam Ratulangi Manado.

Pertiwi, T.K., F. M. I.Pratama. 2012. Pengaruh Kinerja Keuangan, Good Corporate Governance terhadap Nilai Perusahaan Food and Beverage. Jurnal Manajemen dan Kewirausahaan,Vol. 14, No. 2: 118-127.

Prastuti, N. K. K., I. G. A. N. Budiasih. 2015. PengaruhGoodCorporate Governancepada Nilai Perusahaan dengan ModerasiCorporate Social Responsibility. E-Jurnal Akuntansi Universitas Udayana 13.1: 114-129.

Purbopangestu, H. Wisnu, Subowo. 2014. Pengaruh Good Corporate Governance terhadap Nilai Perusahaan dengan Corporate Social Responsibility sebagai Variabel Intervening. Accounting Analysis Journall.

Putra, I. K. D. A., Ni G. P. Wirawati. 2013. Pengaruh Kepemilikan Manajerial terhadap Hubungan antara Kinerja dengan Nilai Perusahaan.E-jurnalAkuntansi Universiitas Udayana 5.3: 639-651.

Rano, Pratana P. Mediatuty. 2011. Struktur Kepemilikan, Good Corporate Governance, Investasi dan Nilai Perusahaan: Suatu Pengujian Sistem Persamaan Simultan. Jurnal Akuntansi, Vol. 1, No. 1: 40-66.

Ridwan, Mochammad, A. Gunardi. 2013. Peran Mekanisme Corporate Governance sebagai Pemoderasi Praktik Earning Management terhadap Nilai Perusahaan. Jurnal Trikonomika, Vol. 12, No. 1: 49-60.

Rosiana, G. A., G. Juliarsa G., M. R. Sari. 2013. Pengaruh Pengungkapan CSR terhadap Nilai Perusahaan dengan Profitabilitas sebagai Variabel Pemoderasi. E-Jurnal Universitas Udayana 5(3): 723-738.

Rupilu, Wilsna. 2011. Pengaruh Mekanisme Corporate Governance terhadap Kualitas Laba dan Nilai Perusahaan pada Perusahaan Manufaktur yang Terdaftar di Bursa Efek Indonesia. Jurnal Akuntansi, Manajemen Bisnis dan Sektor Publik (JAMBSP), Vol. 8, No. 1: 101-127.

Sakti, K. L., P. Nugroho. 2012. Pengaruh Good Corporate Governance terhadap Hubungan antara Kinerja Keuangan dengan Nilai Perusahaan. Jurnal Manajemen, Akuntansi dan Ekonomi Pembangunan, Vol. 10, No. 2

Santoso, Singgih. 2012. Aplikasi SPSS pada Statistik Parametrik. Cetakan I. Jakarta: PT Elex Media Komputindo.

Sekaran, Uma, Roger Bougie. 2013. Sixth Edition. Research Methods for Business. United Kingdom: Jhon Wiley \& Sons Ltd.

Sianturi, M. WantiErnita.2015.Pengaruh Kinerja Keuangan terhadap NilaiPerusahaan Manufaktur Sektor Industri Barang Konsumsi di BEl.E-Journal Administrasi Bisnis, Vol. 3, No. 2: 282-296. Universitas Mulawarman.

Sjahrial, Dermawan dan Djahotman Purba. 2011. Analisa Laporan Keuangan. Jakarta: Mitra Wacana Media. 
Suroto. 2015. Pengaruh Keputusan Investasi, Keputusan Pendanaan dan Kebijakan Dividen terhadap Nilai Perusahaan (Studi Empiris pada Perusahaan LQ-45 yang Terdaftar di Bursa Efek Indonesia Periode Februari 2010-Januari 2015). Jurnal IImiah UNTAG Semarang. Vol. 4, No. 3: 100-117.

Timbuleng F., S.C. Nangoy., I.S. Saerang. 2015. Pengaruh Faktor Likuiditas, Leverage, NPM dan ROI terhadap Nilai Perusahaan (Studi pada Perusahaan Consumer Goods yang Terdaftar di Bursa Efek Indonesia Periode 2010-2013). Jurnal EMBA. Vol. 3 No. 2: 546-557.

Wardoyo, T. M. Veronica. 2013. Pengaruh Good Corporate Governance, Corporate Social Responsibility \& Kinerja Keuangan terhadap Nilai Perusahaan. Jurnal Dinamika Manajemen. Vol. 4, No. 2: 132-149. 
LAMPIRAN

Tabel 1. Prosedur Pemilihan Sampel

\begin{tabular}{llcc}
\hline No. & \multicolumn{1}{c}{ Keterangan } & Jumlah & Data \\
\hline 1. & $\begin{array}{l}\text { Perusahaan non keuangan yang terdaftar di Bursa Efek Indonesia } \\
\text { periode } 2013 \text { sampai } 2015 .\end{array}$ & 410 & 1.230 \\
2. $\begin{array}{l}\text { Perusahaan yang tidak menerbitkan laporan keuangan tahunan yang } \\
\text { berakhir pada tanggal 31 Desember. }\end{array}$ & $(8)$ & $(24)$ \\
3. Perusahaan yang tidak menyajikan laporan keuangan dalam bentuk & $(74)$ & (222) \\
$\quad \begin{array}{l}\text { mata uang rupiah. } \\
\text { 4. Perusahan yang tidak menghasilkan laba secara konsisten selama } \\
\text { periode penelitian. }\end{array}$ & $(113)$ & (339) \\
5. Perusahan yang tidak memiliki data kepemilikan manajerial secara & $(111)$ & (333) \\
k. $\begin{array}{l}\text { Pensisten selama periode penelitian. } \\
\text { saham yang lengkap selama periode penelitian. }\end{array}$ & $(13)$ & (39) \\
Total perusahaan non keuangan yang digunakan sebagai sampel penelitian & 91 & 273 \\
\hline
\end{tabular}

Sumber: Kriteria Penelitian

Tabel 2. Deskriptif Statistik

\begin{tabular}{lccccc}
\hline Variabel & $\mathbf{N}$ & Minimum & Maksimum & Mean & Std.Deviation \\
\hline FV & 257 & 0.2198 & 4.7663 & 1.426917 & 0.8023887 \\
UDK & 257 & 2.0000 & 22.0000 & 4.420233 & 2.5423098 \\
DKI & 257 & 0.1429 & 0.7500 & 0.387272 & 0.0950177 \\
INST & 257 & 0.0000 & 0.9776 & 0.633681 & 0.2052748 \\
MNJRL & 257 & 0.0000 & 0.6725 & 0.058572 & 0.1148866 \\
KA & 257 & 0.0000 & 6.0000 & 3.093385 & 0.5144732 \\
ROE & 257 & 0.0004 & 0.3893 & 0.124326 & 0.0766458 \\
DER & 257 & 0.0709 & 5.1524 & 1.039755 & 0.8783887 \\
TAT & 257 & 0.0123 & 3.1891 & 0.910383 & 0.6278880 \\
LIQ & 257 & 0.2405 & 14.0300 & 2.443618 & 2.3600342 \\
\hline
\end{tabular}




\section{Hasil Uji Heteroskedastisitas}

\section{Coefficients $^{\mathrm{a}}$}

\begin{tabular}{|c|c|c|c|c|c|c|}
\hline & \multirow{2}{*}{ Model } & \multicolumn{2}{|c|}{$\begin{array}{l}\text { Unstandardized } \\
\text { Coefficients }\end{array}$} & \multirow{2}{*}{$\begin{array}{c}\begin{array}{c}\text { Standardized } \\
\text { Coefficients }\end{array} \\
\text { Beta }\end{array}$} & \multirow{2}{*}{$\mathrm{t}$} & \multirow{2}{*}{ Sig. } \\
\hline & & B & Std. Error & & & \\
\hline \multirow[t]{10}{*}{1} & (Constant) & .157 & .220 & & .716 & .475 \\
\hline & UDK & -.011 & .010 & -.064 & -1.049 & .295 \\
\hline & DKI & .340 & .254 & .076 & 1.337 & .182 \\
\hline & INST & -.095 & .146 & -.046 & -.649 & .517 \\
\hline & MNJRL & .408 & .258 & .110 & 1.583 & .115 \\
\hline & KA & -.023 & .050 & -.027 & -.455 & .649 \\
\hline & ROE & 2.677 & .334 & .481 & 8.008 & .000 \\
\hline & DER & .001 & .031 & .002 & .031 & .976 \\
\hline & TAT & -.046 & .041 & -.068 & -1.130 & .260 \\
\hline & LIQ & .031 & .012 & .173 & 2.638 & .009 \\
\hline
\end{tabular}

a. Dependent Variable: ARES_1

\section{Hasil Uji Multikolinearitas}

Coefficients $^{a}$

\begin{tabular}{|c|c|c|c|c|c|c|c|c|}
\hline & \multirow{2}{*}{ Model } & \multicolumn{2}{|c|}{$\begin{array}{c}\text { Unstandardized } \\
\text { Coefficients }\end{array}$} & \multirow{2}{*}{$\begin{array}{c}\begin{array}{c}\text { Standardized } \\
\text { Coefficients }\end{array} \\
\text { Beta }\end{array}$} & \multirow{2}{*}{$t$} & \multirow{2}{*}{ Sig. } & \multicolumn{2}{|c|}{$\begin{array}{l}\text { Collinearity } \\
\text { Statistics }\end{array}$} \\
\hline & & B & Std. Error & & & & Tolerance & VIF \\
\hline \multirow[t]{10}{*}{1} & (Constant) & .352 & .360 & & .976 & .330 & & \\
\hline & UDK & .085 & .017 & .269 & 5.035 & .000 & .798 & 1.253 \\
\hline & DKI & .751 & .417 & .089 & 1.799 & .073 & .932 & 1.073 \\
\hline & INST & -.056 & .240 & -.014 & -.232 & .817 & .603 & 1.658 \\
\hline & MNJRL & .882 & .423 & .126 & 2.085 & .038 & .620 & 1.613 \\
\hline & $\mathrm{KA}$ & -.103 & .081 & -.066 & -1.265 & .207 & .837 & 1.195 \\
\hline & ROE & 5.845 & .549 & .558 & 10.650 & .000 & .828 & 1.207 \\
\hline & DER & -.114 & .052 & -.124 & -2.196 & .029 & .711 & 1.407 \\
\hline & TAT & .050 & .067 & .039 & .739 & .460 & .824 & 1.213 \\
\hline & LIQ & .023 & .019 & .069 & 1.203 & .230 & .694 & 1.440 \\
\hline
\end{tabular}

a. Dependent Variable: FV 


\begin{tabular}{|c|c|c|c|c|c|c|}
\hline \multicolumn{7}{|c|}{$\begin{array}{c}\text { Hasil Uji t } \\
\text { Coefficients }^{a}\end{array}$} \\
\hline & \multirow[t]{2}{*}{ Model } & \multicolumn{2}{|c|}{$\begin{array}{c}\text { Unstandardized } \\
\text { Coefficients }\end{array}$} & \multirow{2}{*}{$\begin{array}{c}\begin{array}{c}\text { Standardized } \\
\text { Coefficients }\end{array} \\
\text { Beta }\end{array}$} & \multirow[t]{2}{*}{$\mathrm{t}$} & \multirow[t]{2}{*}{ Sig. } \\
\hline & & B & Std. Error & & & \\
\hline \multirow[t]{10}{*}{1} & (Constant) & .352 & .360 & & .976 & .330 \\
\hline & UDK & .085 & .017 & .269 & 5.035 & .000 \\
\hline & DKI & .751 & .417 & .089 & 1.799 & .073 \\
\hline & INST & -.056 & .240 & -.014 & -.232 & .817 \\
\hline & MNJRL & .882 & .423 & .126 & 2.085 & .038 \\
\hline & $\mathrm{KA}$ & -.103 & .081 & -.066 & -1.265 & .207 \\
\hline & ROE & 5.845 & .549 & .558 & 10.650 & .000 \\
\hline & DER & -.114 & .052 & -.124 & -2.196 & .029 \\
\hline & TAT & .050 & .067 & .039 & .739 & .460 \\
\hline & LIQ & .023 & .019 & .069 & 1.203 & .230 \\
\hline
\end{tabular}

